\title{
To use or not to use corticosteroids for pneumonia? A clinician's perspective
}

\author{
M. Confalonieri, M. Kodric, M. Santagiuliana, C. Longo, M. Biolo, \\ R. Cifaldi, C. Torregiani, M. Jevnikar
}

\begin{abstract}
To use or not to use corticosteroids for pneumonia? A clinician's perspective. M. Confalonieri, M. Kodric, M. Santagiuliana, C. Longo, M. Biolo, R. Cifaldi, C. Torregiani, M. Jevnikar.

The use of corticosteroids in the management of pneumonia is still a controversial issue. The physicians in daily clinical practice often use corticosteroids in patients with pneumonia for different reasons all over the world. As an example of real life is the frequent use of corticosteroids to treat patients with pneumonia due to H1N1 pandemic influenza in spite of WHO' statements that clearly discouraged this therapy. In fact, the literature up to august 2012 reported a total of 6,650 patients with pneumonia due to $\mathrm{H} 1 \mathrm{~N} 1$ virus infection (of whom 2,515 were ICU patients): corticosteroids were used with various dose regimen in 2404 patients $(37.8 \%)$. The attitude of international guidelines on pneumonia in using steroids do not help the clinician to clearly choice when and how to treat pneumonia with steroids. However, stress doses of corti-
\end{abstract}

costeroids are suggested by some major guidelines on community-acquired pneumonia in case of severe episodes with sepsis. To date, there are 10 randomised controlled trials assessing the effectiveness of corticosteroids for community-acquired pneumonia globally involving 1090 participants . Most of the trials adopted stress doses of glucorticoids for 4-7 days. The evidence from these trials taken separately is weak due to limitations of the studies themselves, but a Cochrane review and a systematic review found benefit using prolonged low doses of glucocorticoids in severe community-acquired pneumonia. Moreover, such a strategy decreases vasopressor dependency and appears to be safe. Nevertheless, larger trials with more patients and clinically important end-points were claimed to provide robust evidence. Finally, infection surveillance is critical in patients treated with corticosteroids, and to prevent the rebound phenomenon, the drug should be weaned slowly.

Monaldi Arch Chest Dis 2012; 77: 2, 94-101.

Keywords: Glucocorticoids, Community-acquired pneumonia, Severe pneumonia, Inflammatory response.

Struttura Complessa Pneumologia, Azienda Ospedaliero-Universitaria “Ospedali Riuniti” di Trieste, Ospedale di Cattinara, Trieste, Italy.

Correspondence: Dr. Marco Confalonieri, Struttura Complessa Pneumologia, Azienda Ospedaliero-Universitaria "Ospedali Riuniti” di Trieste, Ospedale di Cattinara, Strada di Fiume 447, 34149 Trieste, Italy; e-mail: marco.confalonieri@aots.sanita.fvg.it

\section{A long-standing debate for a complex dilemma}

Pneumonia is one of the most common infectious diseases addressed by clinicians. It remains an important cause of morbidity and mortality, with significant economical and social cost [1]. To use or not to use corticosteroids in the management of patients with pneumonia is a long-standing dilemma in the scientific literature with no definitive final response currently $[2,3]$. From the half of the past century to date there were a number of clinical case reports, observational studies, controlled trials, and systematic reviews on the use of systemic corticosteroids in patients with pneumonia, but the scientific debate is still open [4-16]. There is no clear evidence regarding regular use of corticosteroids for each pneumonia, but also there is no evidence to suggest avoiding steroids for any pneumonia. Steroids potentially modulate the marked and persistent activation of the immune system in pneumonia, but the results of different studies on corticosteroids for pneumonia are controversial. Moreover, steroids may have different effects according to the dose regimen. The first statement to be made is that "to use or not to use corticosteroids for pneumonia?" is not a simple question. A part the lack of convincing scientific evidence from the published studies, the problem is complex because pneumonia is not a homogeneous and simple disease, and corticosteroids, in spite of their extended use, are not elementary drugs. Pneumonia may be a community-acquired or a hospital-acquired disease, affecting previously healthy people or with chronic illness and/or defects of the immune system. The microbial etiology of pneumonia is often not characterized at time of diagnosis, and the host response to the infection not always predictable [17]. Prognosis of pneumonia varies considerably from a mild self-limiting disease to a severe one becoming to a life-threatening condition. Corticosteroids can modulate inflammation, suppress the immune system, influence carbohydrate metabolism, protein catabolism, electrolyte balance, and regulate stress response. Moreover, corticosteroids may have genomic and non- genomic effects according to type of drug, administration schemes, and doses. The present review aims to discuss the question "to use 
or not to use corticosteroids for this patient with pneumonia?" from a clinician's perspective, as clinicians face this question in their daily practice. In the past two decades [18-20], with the availability of biomarker assays, longitudinal measurements have shown that persistent (in place of short-lived) elevation of circulating concentrations of inflammatory cytokines over time (dysregulated systemic inflammation) is the central pathogenetic process contributing to morbidity and mortality in community-acquired pneumonia, sepsis, and acute respiratory distress syndrome. At cellular level, patients with dysregulated inflammation have inadequate glucocorticoid receptor-mediated downregulation of inflammatory transcription factor nuclear factor- $\kappa \mathrm{B}$, despite often having increased concentrations of circulating cortisol (systemic inflammation-associated glucocorticoid resistance). Systemic inflammation - associated glucocorticoid resistance can be reversed by increasing glucocorticoid receptor $\alpha$ activation with quantitatively adequate and prolonged glucocorticoid supplementation. In patients with sepsis and ARDS, much evidence supports a strong association between prolonged downregulation, induced by glucocorticoid treatment, of the inflammatory response and improvement in organ physiology [21, 22]. Even short treatment with glucocorticoid is associated with downregulation of glucocorticoid receptor concentrations in most cell types and adrenal insufficiency; without 6-9 days' tapering, rebound systemic inflammation is common and associated with substantial clinical deterioration $[23,24]$. So, the therapeutic consequences of these pathophysiological observations should be that corticosteroidsare used only as a "stress dose" (prolonged low doses until resolution of systemic inflammation) [25]. In this review we avoid discussing experimental and pathophysiological data, but concentrate on the available clinical evidence.

\section{The use of corticosteroids for pneumonia in the "real life": the case of H1N1 virus pneumonia}

The off-label use of corticosteroids by clinicians is widespread and diffused both within the hospital and outpatient clinics. Corticosteroids may be used as a rescue therapy in critical care, but also are familiar drugs to any physician in diverse clinical conditions. In real-life, pneumonia is sometimes treated also with IV or oral corticosteroids and/or oral non-steroidal anti-inflammatory drugs (NSAIDS) to reduce the lung tissue inflammation, regardless of the type of pneumonia and organism or type of irritation or foreign substances involved. It is quite difficult to determine the proportion of patients with CAP currently treated with corticosteroids in the real life, not considering the differences among locations of care, specialisation of the physicians, criteria to evaluate severity of pneumonia, microbiologic etiology, and so on. Some trials on the efficacy of glucocorticoids in CAP have clearly permitted the use of steroids also in the placebo arm for rescue purpose or in case of sepsis, so confounding the interpretation of the results on a intention-to-treat basis [12]. As an example of the general confusion surrounding this issue, is the case of the H1N1 virus influenza. The World Health Organization (WHO) clearly discouraged treatment with steroids during the recent $\mathrm{H} 1 \mathrm{~N} 1$ virus pandemic [26], but several large observational studies from real-life reported the use of corticosteroids in a consistent portion of patients with pneumonia, particularly the severe ones admitted to Intensive Care Unit (ICU) (table 1) [27-49]. The total number of patients reported in these studies was 6,650 (of whom 2,515 were ICU patients), corticosteroids were used with various or unknown dose regimen in 2404 patients. Some patients were treated with steroids being affected by chronic obstructive pulmonary disease (COPD) or asthma, but most of them had pneumonia. Noticeably, the percentage of patients admitted to hospital, and then treated with corticosteroids was unexpectedly high in the cohort population of observational studies on $\mathrm{H} 1 \mathrm{~N} 1$ virus infection $(37.8 \%)$. The reported effects of corticosteroids during the $2009 \mathrm{H} 1 \mathrm{~N} 1$ pandemic were varied, but no prospective randomised study was performed. The various results reported in these cohort studies and case series reflect that corticosteroids are broadly used, more than the amount of evidence about its effectiveness on viral pneumonia. Registries and retrospective cohorts usually aim at describing the natural history of a disease in the real life and not at investigating interventions like only randomized double-blind trials can do. There are numerous examples of interventions found to be harmful in cohort studies and not in subsequent randomised trials, such as the use of the Swan Ganz catheter [50]. Nevertheless, there was no clear evidence in the literature for increased mortality or survival with corticosteroids, neither in real life. The common practice in real life seems to promote the use of corticosteroids for severe pneumonia and critically ill patients more than in mild-to-moderate cases, but the decision to adopt or not this adjunctive therapy for pneumonia cannot be based only on observational study reports $[51,52]$.

\section{The recommendations of the international guidelines}

The most renowned guidelines by international and national scientific organisations recognize evidence-based methodology to cover the principal aspects of pneumonia care. Whilst most societies have restricted their guidelines to Community-Acquired Pneumonia (CAP), the ATS-IDSA (American Thoracic Society/Infectious Diseases Society of America) distinguished CAP from Hospital-Acquired Pneumonia/Health Care-Acquired Pneumonia/Ventilator-Acquired Pneumonia (HAP/ HCAP/VAP) by mean of two different consensus statements [53, 54], while the European Respiratory Society (ERS) addresses all aspects of care for respiratory tract infections both in the community and hospital settings [55]. The main objective of these statements is to standardize diagnosis and definitions, and to rationalise antibiotic empyric treatment based on the prevalence of different 


\begin{tabular}{|c|c|c|c|c|c|}
\hline $1^{\text {st }}$ Author, Country & CS treated/all patients & Dose regimen & CS outcome & CS Adverse effects & Indications \\
\hline $\begin{array}{l}\text { Brun-Buisson, France, } \\
\text { Switzerland }\end{array}$ & $83 / 208$ & $\begin{array}{l}270 \mathrm{mg} / \mathrm{d} \mathrm{HC} \\
\text { for } 11 \text { days }\end{array}$ & $\begin{array}{l}\text { Steroids more deaths, } \\
(33.7 \text { vs. } 16.8 \%)\end{array}$ & Unknown/NA & ARDS/Pneumonia \\
\hline Domínguez-Cherit, Mexico & $40 / 52$ & Unknown/NA & Unknown/NA & Unknown/NA & Unknown/NA \\
\hline Kim, Korea & $107 / 245$ & Unknown/NA & $\begin{array}{l}\text { 90-d mortality } 54 \% \text { steroids } \\
\text { vs } 31 \% \text { non-steroid group }\end{array}$ & Unknown/NA & $\begin{array}{l}\text { Lower tract infections, } \\
\text { pneumonia, ARDS }\end{array}$ \\
\hline Linko, Finland & $72 / 132$ & Stress dose & $\begin{array}{l}\text { No difference in mortality } \\
\text { albeit steroids were used } \\
\text { in more severe patients }\end{array}$ & Unknown/NA & $\begin{array}{l}\text { Acute respiratory failure, } \\
\text { Pneumonia/ARDS }\end{array}$ \\
\hline Han, China & $46 / 83$ & Various & $\begin{array}{l}\text { Increased rate of critical } \\
\text { illness/death }\end{array}$ & NA & Pneumonia \\
\hline Perez-Padilla, Mexico & $7 / 18$ & $\begin{array}{l}\text { HC300 mg/day } \\
\text { or MP60 mg/day }\end{array}$ & $\begin{array}{c}3 \text { survived } \\
4 \operatorname{died}(\mathrm{p}=0.32)\end{array}$ & Unknown/NA & Pneumonia \\
\hline Diaz, Spain & $136 / 372$ & Unknown/NA & Unchanged mortality-LoS & Unknown/NA & Pneumonia \\
\hline Kumar, Canada & $85 / 168$ & Unknown/NA & Unknown/NA & Unknown/NA & ARDS \\
\hline Jain, USA & $86 / 239$ & Unknown/NA & Unknown/NA & Unknown/NA & Comorbidities (e.g. COPD) \\
\hline Gomez-Gomez, Mexico & $16 / 50$ & Unknown/NA & Unknown/NA & Unknown/NA & Pneumonia \\
\hline Kidd, UK & $1 / 1$ & $\mathrm{MP} 140 \mathrm{mg} \rightarrow 30 \mathrm{mg}$ qds & 1 survived & None & Pneumonia \\
\hline Chang, Taiwan & $13 / 48$ & Unknown/NA & Unknown/NA & Unknown/NA & Respiratory illness \\
\hline Quispe-Laime, Argentina & $13 / 13$ & $\begin{array}{c}\mathrm{HC} 300 \mathrm{mg} / \mathrm{d} \text { or MP } \\
1 \mathrm{mg} / \mathrm{kg} / \text { day for } 21 \text { days }\end{array}$ & $12 / 13$ survived & None & $\begin{array}{c}\text { Pneumonia/ } \\
\text { ARDS/severe sepsis }\end{array}$ \\
\hline Yang, China & $1487 / 3066$ & NA & NA & NA & Pneumonia \\
\hline Myles, UK & $302 / 1083$ & Unknown/NA & $\begin{array}{l}\text { CS reduced rate of critical } \\
\text { illness/deaths in asthmatics }\end{array}$ & Unknown/NA & Asthma, COPD, Pneumonia \\
\hline Lee, Korea & $17 / 116$ & $10 \mathrm{mg} / \mathrm{kg} / \mathrm{d} \mathrm{MP}$ for $1 \mathrm{w}$ tapering & $17 / 17$ survived & None & Pneumonia/ALI-ARDS \\
\hline $\begin{array}{l}\text { Martin-Loeches, Spain/Brazil/ } \\
\text { Portugal/France/Argentina/ } \\
\text { UK/Colombia/Ecuador }\end{array}$ & $126 / 220$ & $\begin{array}{c}>24 \mathrm{mg} / \mathrm{d} \mathrm{MP},>30 \mathrm{mg} / \mathrm{d} \mathrm{P}, \\
\text { diverse duration }\end{array}$ & NA & $\begin{array}{l}\text { HAP } 26.2 \% \text { in CS } \\
\text { versus } 13.8 \%\end{array}$ & $\begin{array}{l}\text { Pneumonia, ARDS, } \\
\text { Asthma, COPD }\end{array}$ \\
\hline Sun, China & $12 / 18$ & Unknown/NA & Unknown/NA & Unknown/NA & ARDS \\
\hline Chien, Taiwan & $21 / 96$ & Different dosages & CS correlates with death & Bacterial infections & Pneumonia \\
\hline Rello, Spain & $11 / 32$ & Unknown/NA & Unknown/NA & Unknown/NA & Unknown/NA \\
\hline CDC, USA & $5 / 10$ & Unknown/NA & Unknown/NA & Unknown/NA & ARDS \\
\hline Webb, Australia/NZ & $91 / 494$ & Unknown/NA & Unknown/NA & Unknown/NA & ARDS/severe pneumonia \\
\hline Confalonieri, Italy & $8 / 8$ & MP $1 \mathrm{mg} / \mathrm{kg}$ for $7-21$ day & $\begin{array}{c}8 / 8 \text { survived } \\
2 \text { underwent invasive MV }\end{array}$ & $\begin{array}{l}\text { Hyperglycemia 50\%, } \\
\text { infections 37\% }\end{array}$ & Severe Pneumonia \\
\hline
\end{tabular}

$\mathrm{NA}=$ Not Available; $\mathrm{CS}$ = corticosteroids; $\mathrm{HC}$ = Hydrocortisone; LoS = Length of stay in Hospital; MP = MethylPrednisolone; $\mathrm{P}$ = Prednisone; COPD = Chronic Obstructive Pulmonary Disease; ARDS = Acute Respiratory Distress Syndrome; ALI = Acute Lung Injury; HAP = Hospital Acquired Pneumonia.

causative organisms as well as disease severity. So, all guidelines for the management of adult pneumonia pay little or no attention to other treatments than antibiotics, corticosteroids included. Table 2 shows the different attitude towards the use of corticosteroids for pneumonia in the most cited guidelines [53-56]. The recommendations regarding the use of corticosteroids in pneumonia are different in diverse guidelines, and this fact is unsurprising giving that there is a lack of quality 
Table 2. - Recommendations regarding the use of corticosteroids for pneumonia in the most recent principal guidelines

\begin{tabular}{|c|c|c|c|c|}
\hline Guidelines & ATS/IDSA & ATS/IDSA & ERS/ESCMID & BTS \\
\hline Type of pneumonia & CAP & HAP-HCAP-VAP & $\begin{array}{l}\text { Lower respiratory } \\
\text { tract infections }\end{array}$ & CAP \\
\hline Year & 2007 & 2005 & 2011 & 2009 \\
\hline $\begin{array}{l}\text { Use of corticosteroids } \\
\text { recommended? }\end{array}$ & $\begin{array}{l}\text { Yes, stress-dose } \\
\text { (hydrocortisone } \\
200-300 \mathrm{mg} / \mathrm{d} \text { ) }\end{array}$ & No mention & No & Not routinely \\
\hline When & $\begin{array}{l}\text { Severe pneumonia } \\
\text { with occult adrenal } \\
\text { insufficiency }\end{array}$ & NA & $\begin{array}{l}\text { Corticosteroids } \\
\text { are not recommended } \\
\text { for pneumonia, unless } \\
\text { supportive care for sepsis }\end{array}$ & $\begin{array}{l}\text { Steroids are not } \\
\text { recommended } \\
\text { in routine treatment } \\
\text { of severe CAP }\end{array}$ \\
\hline $\begin{array}{l}\text { Grade of recommendation, } \\
\text { level of evidence }\end{array}$ & $\begin{array}{l}\mathrm{B} \\
\mathrm{II}\end{array}$ & NA & $\begin{array}{l}\text { A } \\
\text { III }\end{array}$ & $\begin{array}{c}\text { A } \\
\text { I-II }\end{array}$ \\
\hline
\end{tabular}

evidence behind the majority of the guideline recommendations, as Woodhead addressed in a recent Editorial [57]. In fact, only between $6.5 \%$ and $21 \%$ of guidelines are based on "best-level" evidence [57]. Obviously, when guidelines differ it is often for lack of robust evidence, such as the case of corticosteroids for pneumonia. Nevertheless, the only recommendation for corticosteroid therapy for patients with pneumonia is in case of severe CAP with sepsis $[53,56]$. No other recommendation for the practical clinician is forthcoming to date from guidelines.

\section{Community-acquired and hospital acquired pneumonia trials and corticosteroids use}

\section{CAP}

All the randomised controlled trials (RCTs) on the use of corticosteroids for pneumonia were performed in patients with CAP. Until the last decade of the past century there were influent trials on the use of high doses of corticosteroids for 48 hours showing negative effects in patients with sepsis, also due to pneumonia. Subsequently, new knowledge of the mechanisms of corticosteroids stimulate new clinical studies with corticosteroids based on stress doses (prolonged low doses) in patients with sepsis, ARDS, and also pneumonia [58]. It was recognised that only a stress dose can activate the genomic effect of steroids. Moreover, the early interruption of glucocorticoids may be dangerous because of a rebound effect on pro-inflammatory cytokines [23].To date, there are 10 randomised controlled trials (RCTs) assessing the effectiveness of corticosteroids for community- acquired pneumonia involving 1090 participants (table 3). Most of the trials adopted stress doses of glucorticoids for 4-7 days. The evidence from these RCTs taken separately is weak due to limitations of the studies themselves (different dose regimens, primary endpoints not clinically important, use of corticosteroids as rescue therapy also for controls, diverse pneumonia severity, small population study). Large trials with more patients and clinically important end-points are needed to provide robust evidence. Nevertheless, actually the overall effect of low prolonged dose of corticosteroids is more beneficial for patients with severe pneumonia (short length of hospital stay and duration of mechanical ventilation, time to improvement of oxygenation and chest X-ray, less incidence of severe sepsis and multiple organ failure syndrome) [4, 10-13, 25]. If corticosteroids are administered, infection surveillance, avoidance of neuromuscular blockers, and gradual taper of corticosteroids are recommended.

\section{HAP-VAP}

There were no studies to date specifically addressing to use corticosteroids for patients with HAP. Some studies tested the hypothesis that corticosteroids may reduce or increase the risk to develop hospital acquired pneumonia, especially ICUacquired ones, but the results were conflicting because of the several flaws due to different dose regimens, study population, standardised interventions, and so on. As an example is the case of severe trauma. Pneumonia is a looming threat for trauma patients, the overall incidence of post-traumatic pneumonia is $40-60 \%$, mainly in patients with traumatic brain injury. Early post-traumatic pneumonia may increases the duration of mechanical ventilation, hospitalisation and the risk of death. The MRC CRASH trial (corticosteroid andomisation after significant head injury) is a large international double-blind randomised placebo-controlled trial of the effect of early administration of a 48-h infusion of methylprednisolone on the risk of death 


\begin{tabular}{|c|c|c|c|c|c|}
\hline 1st Author, year & $\begin{array}{c}\text { \# patients, } \\
\text { Primary Outcome }\end{array}$ & CS dose regimen & Severity of pneumonia & Results & Study limitations \\
\hline $\begin{array}{l}\text { Cao, 2007 } \\
\text { [ref. 9] }\end{array}$ & $\begin{array}{l}\text { 120, period until } \\
\text { symptoms are resolved }\end{array}$ & Budesonide & $\begin{array}{l}\text { Mild to moderate } \\
\text { pneumonia }\end{array}$ & $\begin{array}{l}\text { CS reduces the duration } \\
\text { of symptoms and number } \\
\text { relapses }\end{array}$ & $\begin{array}{l}\text { Small sample size, } \\
\text { bias in study design }\end{array}$ \\
\hline $\begin{array}{l}\text { Confalonieri, } 2005 \\
\text { [ref. 4] }\end{array}$ & $\begin{array}{l}56, \mathrm{PaO}_{2}: \mathrm{FiO}_{2} \\
\text { improvement }\end{array}$ & $\begin{array}{l}200 \mathrm{mg} \text { HC bolus, then } \\
240 \mathrm{mg} / \text { day HC for } 7 \text { day }\end{array}$ & $\begin{array}{l}\text { Severe pneumonia } \\
\text { (ATS 1991), most } \\
\text { of them with sepsis }\end{array}$ & $\begin{array}{l}\text { Earlier } \mathrm{PaO}_{2}: \mathrm{FiO}_{2} \\
\text { improvement with } \mathrm{CS}\end{array}$ & $\begin{array}{l}\text { Early interruption } \\
\text { for more deaths } \\
\text { in the placebo arm }\end{array}$ \\
\hline $\begin{array}{l}\text { van Woensel, } 2003 \\
\text { [ref. 8] }\end{array}$ & 85, duration of MV & $\begin{array}{l}\text { IV DEX } 0.15 \mathrm{mg} / \mathrm{kg} \\
\text { 6-hourly for } 48 \text { hours }\end{array}$ & $\begin{array}{l}\text { Mild pneumonia, } \\
\text { bronchiolitis }\end{array}$ & $\begin{array}{l}\text { CS Increased LoS, } \\
\text { need for MV increased }\end{array}$ & $\begin{array}{l}\text { Several drop-outs } \\
\text { or losses to follow up }\end{array}$ \\
\hline $\begin{array}{l}\text { Marik, } 1993 \\
\text { [ref. 5] }\end{array}$ & $\begin{array}{l}\text { 30, mortality, ICU LoS, } \\
\text { and serum TNFalpha } \\
\text { level }\end{array}$ & $\begin{array}{c}10 \mathrm{mg} / \mathrm{kg} \text { of } \\
\text { hydrocortisone or placebo } \\
\text { IV } 30 \mathrm{~min}- \\
\text { prior to starting } \\
\text { antibiotic therapy }\end{array}$ & Severe pneumonia & $\begin{array}{l}\mathrm{CS} \text { reduced LoS } \\
\text { and duration of MV }\end{array}$ & $\begin{array}{l}\text { Very short duration } \\
\text { interventional therapy } \\
\text { with CS } \\
\text { (possible rebound) }\end{array}$ \\
\hline $\begin{array}{l}\text { McHardy, } 1972 \\
\text { [ref. 6] }\end{array}$ & $\begin{array}{l}\text { 126, time to clinical } \\
\text { resolution }\end{array}$ & $20 \mathrm{mg} /$ day P & Mild & $\begin{array}{l}\text { No difference between } \\
\text { groups }\end{array}$ & $\begin{array}{l}\text { Small sample size, } \\
\text { bias in study design }\end{array}$ \\
\hline $\begin{array}{l}\text { Fernandez-Serrano, } 2011 \\
\text { [ref. 11] }\end{array}$ & $\begin{array}{l}\text { 56, requirement for } \mathrm{MV} \\
\text { and } \mathrm{PaO}_{2}: \mathrm{FiO}_{2} \\
\text { improvement }\end{array}$ & $\begin{array}{l}\text { Bolus iv } 200 \mathrm{mg} \text { MP } \\
\text { then } 20 \mathrm{mg} / 6 \mathrm{~h} \text { for } 3 \text { days, } \\
\text { then } 20 \mathrm{mg} / 12 \mathrm{~h} \text { for } \\
3 \text { days, and finally } \\
20 \mathrm{mg} / \text { day for another } \\
3 \text { days }\end{array}$ & $\begin{array}{l}\text { Severe pneumonia } \\
\text { with ALI }\end{array}$ & $\begin{array}{l}\text { CS reduced need for MV } \\
\text { (not significant) and } \\
\text { imroved } \mathrm{PaO}_{2}: \mathrm{FiO}_{2} \\
\text { significantly earlier } \\
\text { than placebo }\end{array}$ & Small sample size \\
\hline $\begin{array}{l}\text { Sabry, } 2011 \\
\text { [ref. 13] }\end{array}$ & $\begin{array}{l}\quad 80, \mathrm{PaO}_{2}: \mathrm{FIO}_{2}>300 \\
\text { or }>100 \text { than study entry, } \\
\text { and reduced septic shock }\end{array}$ & $\begin{array}{l}\text { Loading dose } 200 \mathrm{mg} \\
\text { over } 30 \mathrm{~min} \text {, followed } \\
\text { by } 300 \mathrm{mg} / \text { day for } 7 \text { days }\end{array}$ & $\begin{array}{l}\text { Intubated ICU-patients } \\
\text { with severe pneumonia }\end{array}$ & $\begin{array}{l}\text { CS significantly improved } \\
\mathrm{PaO}_{2}: \mathrm{FIO}_{2} \text { and SOFA } \\
\text { score at day } 7\end{array}$ & $\begin{array}{l}\text { Small sample size, NIV } \\
\text { was not used for weaning }\end{array}$ \\
\hline $\begin{array}{l}\text { Mikami, } 2007 \\
\text { [ref. 7] }\end{array}$ & $\begin{array}{l}\text { 31, days to normalisation } \\
\text { of } \mathrm{SpO}_{2}\end{array}$ & $40 \mathrm{mg} / \mathrm{d}$ P IV for 3 days & $\begin{array}{c}\text { Moderate and severe } \\
\text { pneumonia }\end{array}$ & $\begin{array}{l}\mathrm{CS} \text { did not faster } \mathrm{SpO}_{2} \\
\text { normalization, } \\
\text { but shortened antibiotic } \\
\text { duration }\end{array}$ & $\begin{array}{l}\text { Small sample size, open } \\
\text { label study design }\end{array}$ \\
\hline $\begin{array}{l}\text { Snijders, } 2010 \\
\text { [ref. 12] }\end{array}$ & 213 , clinical cure at day 7 & $40 \mathrm{mg}$ P IV for 7 days & $\begin{array}{c}\text { Mild-to-severe } \\
\text { hospitalized patients }\end{array}$ & $\begin{array}{l}\text { Primary end-point } \\
\text { not reached }\end{array}$ & $\begin{array}{l}\text { Mainly mild pneumonia, } \\
\text { possibility to receive CS } \\
\text { also for controls }\end{array}$ \\
\hline $\begin{array}{l}\text { Meijvis, } 2011 \\
\text { [ref. 10] }\end{array}$ & 304 , length of hospital stay & $\begin{array}{l}\text { iv DEX ( } 5 \mathrm{mg} \text { once a day) } \\
\text { for } 4 \text { days }\end{array}$ & Mild-to-severe (PSI I--V) & LoS reduction with CS & $\begin{array}{l}\text { Possible use of CS in case } \\
\text { of sepsis with bias } \\
\text { analysis, CS effects not } \\
\text { evaluated if need for MV }\end{array}$ \\
\hline
\end{tabular}

and disability after head injury [59]. The risk of death and severe disability was higher in the corticosteroid group than in the placebo group. Another more recent RCT in ICU- patients with severe traumatic brain injury used stress doses of hydrocortisone (continuous infusion iv $200 \mathrm{mg} / \mathrm{d}$ for 5 days, followed by $100 \mathrm{mg}$ on day 6 and $50 \mathrm{mg}$ on day 7)[60]. This multicentre French study showed that in intubated trauma patients, the use of an intravenous stress-dose of hydrocortisone, compared with placebo, resulted in a decreased risk of hospital- acquired pneumonia. Another very recent observational cohort study [61] performed in a single ICU where systemic methylprednisolone was given for several reasons was contrasting, showed an in- creased development of ICU-acquired pneumonia in patients previously treated with steroids. In adjusted analysis, there was a higher risk of death with steroid use among patients with lower baseline organ dysfunction scores $(\mathrm{P}=0.05)$, and among those without bacteremia $(\mathrm{P}=0.03)$ or acute respiratory distress syndrome $(\mathrm{P}=0.03)$. The conclusion for the clinical practice from the conflicting results of diverse trials may be difficult, but some caveats could be picked up. The use of short-time high doses of corticosteroids should be discouraged in ICUpatients because it is harmful, but a monitored prolonged low dose regimen can be beneficial in selected case with severe sepsis and Adult Respiratory Distress Syndrome (ARDS) [62]. 


\section{Mild-to-moderate pneumonia or only severe pneumonia?}

The definition of severe pneumonia has not yet reached a general consensus. So, different studies on cortisteroids for CAP adopted diverse definition of severity. Nevertheless, most of the patients treated with corticosteroids in RCTs had severe pneumonia with need for ICU admission and/or mechanical ventilation. Among the ten RCTs on corticosteroids in CAP, some were dedicated to patients with severe pneumonia and others included a number of patients with mild and moderate pneumonia. The large Dutch study by Snijders and colleagues [12] found no evidence of efficacy for prednisolone $40 \mathrm{mg}$ once a day for a week in hospitalised CAP patients without severe sepsis, whilst the study by Meijvis et al [10] showed that a 4 day treatment with dexamethasone $5 \mathrm{mg}$ can reduce the length of hospital stay in patients with more severe pneumonia. So, apart from the different half-lives of prednisolone and dexamethasone, we should note that corticosteroids for mild and moderate pneumonia are not indicated. According to the results of RCTs clearer benefits of corticosteroids in patients with pneumonia were demonstrated using stress doses in the presence of cortical insufficiency, ARDS, and severe sepsis. These are the recommendations of the consensus guidelines for patients admitted to the ICU with severe CAP with either shock or acute lung injury [63]. It has been proposed [64] to diagnose cortical insufficiency in the presence of cortisol blood levels $\leq 10 \mu \mathrm{g} / \mathrm{dL}$ or increase in cortisol levels $\leq 9 \mu \mathrm{g} / \mathrm{dL}$ after cosynotropin stimulation test. The diagnosis of cortical insufficiency is not always available and easy at bedside in daily practice, albeit it should be preferable before to administer steroids. A positive linear correlation has been shown between cortisol levels and the severity of the CAP, but corticosteroids may change this [65]. In addition, genetic information could help to identify patients for a more personalized treatment. Nevertheless, common practical criteria for severe pneumonia that could be taken in consideration by the clinician for glucocorticoid therapy are: $\mathrm{PaO}_{2}: \mathrm{FiO}_{2}$ $<250$, respiratory rate $>30 \mathrm{bpm}$, bilateral infiltrates at chest-X-ray, and $>3-4$ fold higher than normal CRP levels. When the decision to use corticosteroids is taken, the patient should be protected with anti- acid agents, and strictly monitored to early detect infections, hyperglicemia, hypokaliemia, and other possible adverse events. Steroids should be stopped in patients whose vasopressor dependency (dosage of norepinephrine or equivalent of greater than $0.1 \mu \mathrm{g} / \mathrm{kg}$ per minute) has not improved within 2-4 days of glucocorticoids [66].

\section{Conclusions}

The debate about the use of corticosteroids as adjunctive therapy for patients with pneumonia is far from being concluded. In spite of a great number of patients included in RCTs, further more robust data is needed regarding the optimal choice of the patients and glucocorticoids dose regimen. Nevertheless, from a clinical point of view, the amount of knowledge obtained from recent RCTs make it feasible to consider the use of stress doses

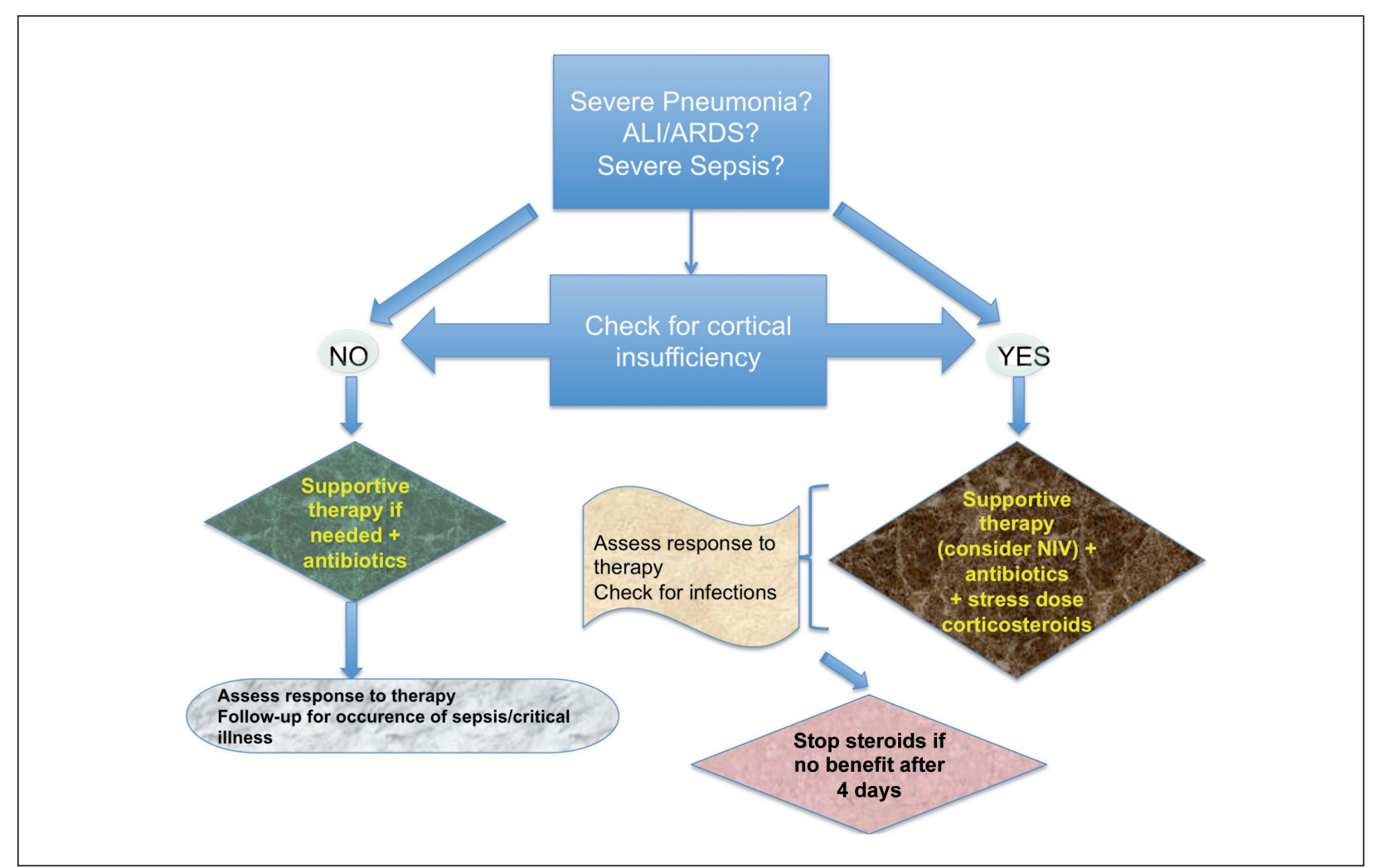

Fig. 1. - Decisional Flow-chart to consider the use of corticosteroids for pneumonia. NIV = Noninvasive ventilation. 
of corticosteroids for pneumonia when a cortical insufficiency is diagnosed, or when Acute Lung Injury (ALI)/ARDS, severe sepsis, and/or severe pneumonia criteria are detectable (figure 1). The risk/benefit ratio of glucocorticoids should be always determined in each patient. A prolonged course (at least 7 to 10 days) of low-dose corticosteroids (e.g. Hydrocortisone $200 \mathrm{mg} /$ day) may be helpful in patients with severe pneumonia within 12 hours of the onset of shock [64]. While the outcome benefit of prolonged low-dose glucocorticoids remains to be determined, such a strategy decreases vasopressor dependency and appears to be safe (no excess mortality, infections, myopathy). In fact, infection surveillance is critical in patients treated with corticosteroids, and to prevent the rebound phenomenon, the drug should be weaned slowly.

\section{References}

1. Armstrong GL, Conn LA, Pinner RW. Trends in infectious disease mortality in the United States during the 20th century. JAMA 1999; 281: 61-66.

2. Annanne D, Meduri GU. Corticosteroids for community acquired pneumonia: time to act! Crit Care 2008; 12: 166 (doi: 10.1186/cc6940).

3. Povoa P, Salluh JIF. What is the role of steroids in pneumonia therapy? Curr Opin Infect Dis 2012; 25: 199-204.

4. Confalonieri M, Urbino R, Potena A, et al. Hydrocortisone infusione for severe community acquired pneumonia. A preliminary randomized study. Am J Respir Crit Care Med 2005; 171: 242-248.

5. Marik P, Kraus P, Sribante J, Havlik I, Lipman J, Johnson DW. Hydrocortisone and tumor necrosis factor in severe community-acquired pneumonia: a randomized controlled study. Chest 1993; 104: 389-392.

6. McHardy VU, Schonell ME. Ampicillin dosage and use of prednisolone in treatment of pneumonia: co-operative controlled trial. Brit Med J 1972; 4 (5840): 569-73.

7. Mikami K, Suzuki M, Kitagawa H, Kawakami M, Hirota N, Yamaguchi $\mathrm{H}$. Efficacy of corticosteroids in the treatment of community-acquired pneumonia requiring hospitalisation. Lung 2007; 185: 249-55.

8. van Woensel JB, van Aalderen WM, de Weerd W, Jansen NJ. Dexamethasone for treatment of patients mechanically ventilated for lower respiratory tract infection caused by respiratory syncytial virus. Thorax 2003; 58: 383-7.

9. Cao LF, Lu YM, Ma HG, Ma M. Budesonide inhaling auxiliary therapy after mycoplasma pneumoniae infection of children. Internat J Respir 2007; 27: 567-9.

10. Meijvis S, Hardeman H, Remmelts HHF, et al. Dexamethasone and length of hospital stay in patients with community-acquired pneumonia: a randomised, double-blind, placebo-controlled trial. Lancet 2011; 377: 2023-30.

11. Fernández-Serrano S, Dorca J, Garcia-Vidal C, et al. Effect of corticosteroids on the clinical course of community-acquired pneumonia: a randomized controlled trial. Crit Care 2011; 15: R96.

12. Snijders D, Daniels JMA, de Graaff CS, van der Werf TS, Boersman WG. Efficacy of corticosteroids in community-acquired pneumonia. Am J Respir Crit Care Med 2010; 181: 975-982.

13. Sabry NA, El-Din Omar E. Corticosteroids and ICUcourse of community acquired pneumonia in Egyptian settings. Pharmacol Pharm 2011; 2: 73-81.

14. Garcia-Vidal C, Calbo E, Pascual V, Ferrer C, Quintana S, Garau J. Effects of systemic steroids in patients with severe community-acquired pneumonia. Eur Respir $J$ 2007; 30: 951-956.

15. Monton C, Ewing S, Torres A, et al. Role of glucocorticoids on inflammatory response in nonimmunosuppressed patients with pneumonia: a pilot study. Eur Respir J 1999; 14: 218-220.

16. Wagner HN, Bennett IL, Lasagna L, Cluff LE, Rosenthal MB, Mirick GS: The effect of hydrocortisone upon the course of pneumococcal pneumonia treated with penicillin. Bull Johns Hopkins Hosp 1956; 98: 197-215.

17. Antunes G, Evans SA, Lordan JL, Frew AJ. Systemic cytokine levels in community-acquired pneumonia and their association with disease severity. Eur Respir J 2002; 20: 990-995.

18. Kellum JA, Kong L, Fink MP, Weissfeld LA, et al. Understanding the inflammatory cytokine response in pneumonia and sepsis: results of the Genetic and Inflamma tory Markers of Sepsis (GenIMS) Study. Arch Intern Med 2007; 167: 1655-1663.

19. Yende S, D'Angelo G, Kellum JA, et al, for the GenIMS Investigators. Inflammatory markers at hospital discharge predict subsequent mortality after pneumonia and sepsis. Am J Respir Crit Care Med 2008; 177: 1242-47.

20. Meduri GU, Annane D, Chrousos GP, Marik PE, Sinclair SE. Activation and regulation of systemic inflammation in ARDS: rationale for prolonged glucocorticoid therapy. Chest 2009; 136: 1631-43.

21. Annane D, Bellissant E, Cavaillon JM. Septic shock. Lancet 2005; 365 (9453): 63-78.

22. Meduri GU, Yates CR. Systemic inflammatory-associated glucorticoid resistance and outcome of ARDS. Ann NY Acad Sci 2004; 1024: 24-53.

23. Keh D, Boehnke T, Weber-Cartens S, et al. Immunologic and hemodynamic effects of "low-dose" hydrocortisone in septic shock: a double-blind, randomized, placebo-controlled, cross- over study. Am J Respir Crit Care Med 2003; 167: 512-20.

24. Nawab Q, Golden E, Confalonieri M, Umberger R, Meduri GU. Corticosteroid treatment in severe community-acquired pneumonia: duration of treatment affects control of systemic inflammation and clinical improvement. Intensive Care Med 2011; 37: 1553-4.

25. Annane D, Bellissant E, Bollaert PE, et al. Corticosteroids in the treatment of severe sepsis and septic shock in adults: a systematic review. JAMA 2009, 301: 2349-2361.

26. World Health Organization (2009) Clinical Management of Human Infection with Pandemic (H1N1) 2009: Revised Guidance. Geneva: World Health Organization. http: //www.who.int/csr/ resources/publications/ swineflu/clinical_management_h1n1.pdf (Accessed 6 February 2010).

27. Brun-Buisson C, Richard JC, Mercat A, Thiebaut A, Brochard L. Early corticosteroids in severe Influenza $\mathrm{A} / \mathrm{H} 1 \mathrm{~N} 1$ pneumonia and acute respiratory distress syndrome. Am J Respir Crit Care Med 2011; 183: 1200- 1206.

28. Dominguez-Cherit G, Lapinsky SE, Macias AE, et al. Critically ill patients with 2009 influenza A (H1N1) in Mexico. JAMA 2009; 302: 1880-1887.

29. Kim S-H, Hong S-B, Yun S-C. Corticosteroid treatment in critically ill patients with pandemic influenza A/H1N1 2009 infection. Am J Respir Crit Care Med 2011; 183: 1207-1214.

30. Linko R, Pettila V, Ruokonen E, et al. FINNH1N1study group. Steroid treatment in patients with influenza A (H1N1) infection in Finnish ICUs: an observational study. Acta Anesth Scand 2011; 55: 971-979.

31. Ke Han K, Ma H, An X, Su Y,. Early Use of Glucocorticoids Was a Risk Factor for Critical Disease and Death From pH1N1 Infection. CID 2011; 53: 326-333. 32. Perez-Padilla R, de la Rosa-Zamboni D, Ponce de Leon 
S, et al. INER Working Group on Influenza. Pneumonia and respiratory failure from swine-origin influenza A (H1N1) in Mexico. $N$ Engl J Med 2009; 361: 680-689.

33. Diaz E, Martin-Loeches I, Canadell L, et al. H1N1 SEMICYUC-CIBERES-REIPI Working Group (GETGAG). Corticosteroid therapy in patients with primary viral pneumonia due to pandemic (H1N1) 2009 influenza. $J$ Infect 2012; 64: 311-318.

34. Kumar A, Zarychanski R, Pinto R, et al. Canadian Critical Care Trials Group H1N1 Collaborative. Critically ill patients with 2009 influenza A (H1N1) infection in Canada. JAMA 2009; 302: 1872-1879.

35. Jain S, Kamimoto L, Bramley AM, et al. Hospitalized patients with $2009 \mathrm{H} 1 \mathrm{~N} 1$ influenza in the United States, April-June 2009. N Engl J Med 2009; 361: 1935-44.

36. Gomez-Gomez A, Magana-Aquino M, Garcia-Sepulveda CA,. Severe pneumonia associated with pandemic (H1N1) 2009 outbreak, San Luis Potosi, Mexico. Emerg Infect Dis 2010; 16. doi: 10.3201/eid1601.090941.

37. Kidd Im, Down J, Nastouli E, Shulman R, Grant PR, Howell DC, Singer M. H1N1 pneumonitis treated with intravenous zanamivir. Lancet 2009; 374: 1036.

38. Chang YS, van Hal SJ, Spencer PM, Gosbel IB, Collett PW. Comparison of adult patients hospitalized with pandemic (H1N1) 2009 influenza and seasonal influenza during the "PROTECT" phase of the pandemic response. Med J Aust 2010, 192: 90-93.

39. Quispe-Laime AM, Bracco JD, Barberio PA, et al. H1N1 influenza A virus-associated acute lung injury: response to combination oseltamivir and prolonged corticosteroid treatment. Intensive Care Med 2010; 36: 33-41.

40. Yang S, Cao B, Liang L, Antiviral Therapy and Outcomes of Patients with Pneumonia Caused by Influenza A Pandemic (H1N1) Virus. PLoS ONE 2012; 7: e29652. doi: 10.1371/journal.pone.0029652.

41. Myles P, Nguyen-Van-Tam JS, Sample MG, et al. Differences between asthmatics and non-asthmatics hospitalised with influenza A infection. Eur Respir J 2012 Aug 16 [Epub ahed of print].

42. Lee K, Rhim J, Kang J. Hyperactive immune cells (T cells) may be responsible for acute lung injury in influenza virus infections: A need for early immune-modulators for severe cases. Med Hypotheses 2011; 76: 64-69.

43. Martin-Loeches I, Lisboa T, Rhodes A, et al. The ESICM H1N1 Registry Contributors. Use of early corticosteroid therapy on ICU admission in patients affected by severe pandemic $(\mathrm{H} 1 \mathrm{~N} 1) \mathrm{v}$ influenza A infection. Intensive Care Med 2011; 37: 272-283.

44. Sun JJ, Li C, Wu DW, et al. Eighteen cases of 2009 influenza A H1N1 associated with respiratory failure in adults. Zhongguo Wei Zhong Bing JJ Jiи Yi Хие 2010; 22: 156-160.

45. Chien YS, Su CP, Tsai HT, et al. Predictors and outcomes of respiratory failure among hospitalized pneumonia patients with $2009 \mathrm{H} 1 \mathrm{~N} 1$ influenza in Taiwan. $J$ Infect Dis 2010; 60: 168-74

46. Rello J, Rodriguez A, Ibanez P, et al. H1N1 SEMICYUC Working Group. Intensive care adult patients with severe respiratory failure caused by influenza A (H1N1) in Spain. Crit Care 2009; 13: R148.

47. CDC estimates of 2009 H1N1 influenza cases, hospitalizations and deaths in the United States, April 2009February 13, 2010. Atlanta: Centers for Disease Control and Prevention, 2010, Available: http: //flu.gov/individualfamily/ about/h1n1/estimates_2009_h1n1.html. Accessed April 9, 2010

48. Webb SAR, Seppelt IM for the ANZIC Influenza Investigators. Pandemic (H1N1) 2009 influenza ("swine flu") in Australian and New Zealand intensive care. Crit Care Resuscitation 2009; 11: 170-2.
49. Confalonieri M, Cifaldi R, Dreas L, Viviani M, Biolo M, Gabrielli M. Methylprednisolone infusion for lifethreatening H1N1-virus infection. Ther Adv Respir Dis 2010; 4: 233-237.

50. Harvey S, Stevens K, Harrison D, et al. An evaluation of the clinical and cost-effectiveness of pulmonary artery catheters in patient management in intensive care: a systematic review and a randomised controlled trial. Health Technol Assess 2006; 10: iii-iv, ix-xi, 1-133.

51. Annane D. Pro: The Illegitimate Crusade against Corticosteroids for Severe H1N1 Pneumonia. Am J Respir Crit Care Med 2011; 183: 1125-1126.

52. Matthay MA, Liu KD. Con: Corticosteroids Are Not Indicated for Treatment of Acute Lung Injury from H1N1 Viral Pneumonia. Am J Respir Crit Care Med 2011; 183: $1127-1128$.

53. Mandell LA, Wunderink RG, Anzueto A, et al. Infectious Diseases Society of America / American Thoracic Society (2007) Consensus guidelines on the management of community-acquired pneumonia in adults. Clin Infect Dis 44 (Suppl 2): S27-72.

54. American Thoracic Society and Infectious Diseases Society of America. Guidelines for the management of adults with hospital-acquired, ventilator associated and healthcare-associated pneumonia. Am J Respir Crit Care Med 2005; 17: 388-416.

55. Woodhead M, Blasi F, Ewig S, et al. Guidelines for the management of adult lower respiratory tract infections. Clin Microbiol Infect 2011; 17 (Suppl 6): E1-59.

56. Lim WS, Baudouin SV, George RC, et al. Guidelines for the management of community acquired pneumonia in adults: update 2009. Thorax 2009; 64 (Suppl III): iii1-iii55. doi: 10.1136/thx.2009.121434iii1.

57. Woodhead M. New guidelines for the management of adult lower respiratory tract infections. Eur Respir $J$ 2011; 38: 1250-1251

58. Confalonieri M, Meduri GU. Glucocorticoid treatment in community-acquired pneumonia. Lancet 2011; 377: 1982-1983.

59. CRASH Trial Collaborators. Final results of MRC CRASH, a randomised placebo-controlled trial of intravenous corticosteroid in adults with head injury: outcomes at 6 months. Lancet 2005; 365: 1957-1959.

60. Roquilly A, Mahe PJ, Seguin P, et al. Hydrocortisone Therapy for Patients with Multiple Trauma: The Randomized Controlled HYPOLYTE Study. JAMA 2011, 305: 1201-1209.

61. Ranzani OT, Ferrer, M, Esperatti M, et al. Association between systemic corticosteroids and outcomes of intensive care unit-acquired pneumonia. Crit Care Med 2012; 40: 2552-2561.

62. Aleti VS, Yende S. Glucocorticoid therapy for trauma: ready for prime-time? Crit Care 2012; 16: 301. http: //ccforum.com/content/16/1/301

63. Marik PE, Pastores S, Annane D, et al. Clinical practice guidelines for the diagnosis and management of corticosteroid in- sufficiency in critical illness: recommendations of an international task force. Crit Care Med 2008; 36: 1937-1949.

64. Hamilton DD, Cotton BA. Cosyntropin as a diagnostic agent in the screening of patients for adrenocortical insufficiency. Clin Pharmacol Adv Appl 2010; 2: 77-82.

65. Remmelts HHF, Meijvis SCA, Kovaleva A, Biesma DH, Rijkers GT, Heijligenberg R. Changes in serum cortisol levels during community-acquired pneumonia: The influence of dexamethasone. Respir Med 2012; 106: 905-908.

66. Marik PE. Glucorticoids in sepsis: dissecting facts from fiction. Crit Care 2011; 15: 158. http: //ccforum. com/content $/ 15 / 3 / 158$ 